\title{
7 Is prose poetry a conspiracy against the Noble Qur'an?
}

But what they're saying is not poetry, right?

Member of audience at Tanta International Poetry Festival, 2015

At a gathering at the Writers' Union in Alexandria that we attended in 2014, a member of the Union seated among the audience claimed that 'prose poetry is a conspiracy against the Noble Qur'an', and demanded a commitment to the discipline of metred and rhymed poetry. In his view, innovation in poetic technique was tantamount to a Western attack on Arabic language and Islamic values. This claim was challenged by others in attendance, and resulted in a lengthy debate. Given the close connection of classical Arabic language and eloquence with the Qur'an and therefore Islamic faith and values, it is not surprising that Arabic poetics can become an issue of contention loaded with identitarian and moral claims. But what exactly is at stake? Why would somebody feel inclined to think that an international conspiracy is set to destroy Islam by promoting highbrow poetry that is only read by a few people?

The precariousness and explosivity of a hard-to-reconcile plurality of stances and views that I have outlined in earlier chapters is not restricted to public spaces and urban divisions. The conflicts that structure urban life often also seep into literary spaces and debates where they intertwine with literary aesthetics in ways that can have grave consequences for the people involved, and which therefore call for closer attention.

In this chapter, I focus on the work and story of one poet, Montaser Abdel Mawgoud in whose oeuvre prose poetry takes a prominent place. Around the same time as the above-described debate took place at the Writers' Union, he was facing personal threats and legal complaints in the school where he worked after some of his colleagues interpreted his newest volume of prose poetry as an attempt to rewrite religious scripture, which in their view was a dangerous heresy, even tantamount to unbelief. Montaser's story also opens the final part of this book where, over the course of two chapters dedicated to two poets, I try to understand the relationship between literary aesthetics, the cultivation of moral and ethical stances, and especially their relationship with different ideas about certainty and uncertainty.

In the context of contemporary Arabic literature, poetic technique is not simply a matter of aesthetic preference; instead, it can provide key insights into how literature contributes to the limits and transformations of societal and moral 
imagination in a specific historical and societal context. Two productive limits and - possibly - transformations are the focus of this chapter. The first concerns transnational and national social milieus and bubbles that allow the normalisation of a specific literary taste as an unmarked category of 'literature'. The second is about how the relationship between humans and God ought to be imagined, expressed in language, and lived.

In the preceding chapters of this book, we have shown that articulations of $a d a b /$ literature that we have encountered in our fieldwork always include aesthetic as well as ethical commitments. The cultivation of adab/literature can thus encourage the crafting of conservative, pious, and authority-oriented attitudes, but also attitudes that go against the grain of conservative moral and religious sensibilities. In Arabic poetry since the twentieth century, a pattern has emerged linking classical poetics with conservative and God-fearing stances on life and politics, and experimental modernist and postmodern ones with leftist-nationalist, bohemian-cosmopolitan, irreverent, and secular stances. Why this is so requires explanation. Why does commitment to classical metres resonate with conservative perspectives? And what is the relationship between experimental aesthetics and postmodern cosmopolitan stances? Why would some people feel threatened and offended by experimental poetry that only circulates in the small bubble of avant-garde literary circles? Poets working in more mainstream styles may also face opposition and censorship when their poetry is understood to deal with religion in an irreverent manner or otherwise offend societal taboos and sensibilities. But prose poetry, a highbrow genre that reaches a limited audience, has the capacity to irritate conservative sensibilities because of both content and form. How can this be explained?

\section{A short genealogy of genres and struggles}

Poems form the oldest known layer of the Arabic textual tradition. Pre-Islamic poetry continues to inform Arabic poetic and rhetorical eloquence today and, alongside the Qur'an, is a formative corpus of Classical Arabic language. The distinction between divine revelation and human poetry is as old as the Qur'an. God states in the Qur'an that His words are not poetry (Qur. 36:69; 69:41-42), and generations of Muslim learned specialists and poets alike have maintained aesthetic standards and practices that set the Qur'an apart from human language. Classical Arabic poetry has a remarkable thematic range, including mystic devotion, romantic love, heroic epics, panegyrics, piety, and irreverence (Van Gelder 2012); it also has a largely constant form that today is known as 'amudi or 'colum- 
nic' poetry - so called because of its double verse structure that in writing looks like two columns. 'Amudi poetry is based on the millennia-old tradition of sixteen Arabic metres, and in its classical form is characterised by the closed semantic unity of the verse and a mono-rhyme that is maintained throughout the poem.

Before the colonial era, poetry was also a main medium of a tradition of cultivating a refined habitus known as adab. Armando Salvatore (2009: 198-200, 2016: 30, 123-125, 2019) argues that before its nineteenth-century reinterpretation as literature on the one hand and civilised habitus on the other, $a d a b$ was a tradition of ethical cultivation that was distinct and, to a degree, independent of the tradition of shari ' $a$. Working on reading practices in early twentieth-century Egypt, Michael Allan (2016) instead appears to assume that adab and religious normativity were indistinguishable until the colonial era, and argues that adab was secularised in this period when powerful critics and readers divided its two inherent dimensions, the content and practice of cultivation, and its medium, poems and stories, into two distinct categories, which made it possible for the second dimension of $a d a b$ to become a translation of the French litterature. Teresa Pepe (2019b) has questioned Allan's narrative of a secular division and break, and argues that contemporary Arabic $a d a b$ as literature continues to carry much of the ethical underpinnings of the older tradition of $a d a b$ as instruction.

Our fieldwork supports Pepe's argument. And whether one agrees with Salvatore's argument about a long history of a soft distinction, or with Allan's argument about the colonial introduction of a hard distinction, in any case, as part of $a d a b$ (in both its classical and modern sense), some poetry has indeed been prone to become a site of language and imagination that is secular in the sense that it produces a differentiation between divine and human powers, between religion and its other; and also in the sense that it is established as an autonomous institutional field (Bourdieu 1998; Jacquemond 2008). Following Pepe, however, I find important to emphasise that this is only true of some poetry, and that the secularity of contemporary literature is far from complete and hardly hegemonic. The internationally prominent cosmopolitan niches of contemporary Arabic literature are indeed a rare stronghold of both political and life-worldly secularisms in an otherwise God-fearing part of the globe. But the secularity of literature has always been contested and incomplete at best, and the literary field's autonomy has been partial ever since its emergence in the early twentieth century (Klemm 1998; Jacquemond 2008). Even the literary avant-gardes - not to mention the mainstream - have not always been as straightforwardly secular as they are commonly depicted to be (Šabasevičiūtè 2018).

With regard to poetry, this means in concrete terms that since the twentieth century, innovations in technique have repeatedly resulted in debates and scan- 
dals where proponents of more conservative aesthetics have seen Arabic and Islamic identity, faith, and values at risk.

A key historical turning point of contemporary Arabic poetry was the innovations introduced mainly by Iraqi and Levantine poets in the early to mid-twentieth century, which resulted in a new genre of metred free verse, today alternatively known as taf'ila (literally, poetic foot) or al-shi'r al-hurr ('free poetry') (Moreh 1976; Jayyusi 1977). Tafila poetry has a structure of single verses of variable lengths, and a rhythm based on verse feet that can be repeated or varied. It can be composed with a mono-rhyme, variable rhymes, or without rhyme. This gives it a wider scope of formal variation than is possible in 'amudi poetry, and yet at the same time it remains recognisably poetry for non-expert audiences because of the maintenance of the verse foot. Some consider taf'ila and al-shi'r al-hurr different names for the same genre, reflecting mid-twentieth-century free verse that relies on a variable metre (e.g. Abdel Sabour 1972; Dunqul 2005; Fakhreddine 2016). Today, some others equate shi'r hurr with free verse, that is, poetry that dispenses with a recognisable rhythm but maintains a verse structure.

Tafila/free verse was scandalous when it emerged. From the 1960s, conservative Egyptian critics were offended by some emerging poets' use of the new technique together with symbolism derived from the Qur'an and pre-Islamic mythology (Moussa-Mahmoud 1996; Toorawa 2004). From the conservative critics' point of view, such poetic innovation threatened both Arabic language and Muslim faith. It was thus not form alone that caused debate; rather, specific poetic forms were associated with specific politics and ethics. However, this association only lasted until the once experimental form became established and popularised. Today, taf'ila/free verse with metre has become the mainstream form of poetry in Egypt. It is no longer clearly associated with any political or ethical stance in particular. Authors of free verse who once were controversial - such as Salah Abdel Sabour (1931-1981) and Amal Dunqul (1940-1983) - have been included in most (but not all, especially not schoolbook) versions of the Egyptian national canon of poetry. But the accusation lives on, now attached to prose poetry.

Prose poetry (qasidat al-nathr) emerged as a dedicated genre in Arabic in around 1960 in the literary circles of Lebanon and Syria, promoted in particular by Adonis and Unsi al-Hajj (Fakhreddine 2016). It has become increasingly popular in literary circles in Egypt since the 1980s and 1990s, but remains a distinctly highbrow and contested poetic form in comparison to the mainstream canonical understanding of poetry as 'measured and rhymed speech that points at a meaning' (Furani 2012: 4). Among Arabic poets and critics, there is little agreement about what constitutes prose poetry proper. One view defines it as all poetry that dispenses with a recognisable verse foot or rhythm (e.g. Furani 2012: 
34, 212-213), distinguished from the metred free verse of taf'ila, and from classical poetry that relies on canonical metres and the double verse form. Others propose a stricter definition that distinguishes prose poetry from all poetry with the verse form, thereby creating a fourth, residual category of free verse without metre. According to the introduction to an anthology of translated and Arabic prose poetry (Al-Janabi 2015, referring to Bernard 1959), prose poetry is based on a prose paragraph that is brief, required for itself, and does not refer to what is outside it. In practice, however, few prose poems meet these strict criteria - including works by poets who subscribe to this definition. ${ }^{1}$

Whatever the definition, prose poetry remains the most controversial Arabic poetic form today. Unlike taf'ila, which merely adapts the canonical understanding of poetry, prose poetry seeks to transform it, and by so doing threatens to unsettle distinctions between genres of speech that have great political and religious significance (Fakhreddine 2016: 248). Non-specialist audiences often don't recognise it as poetry. Whenever authors of prose poetry venture to symposia and circles dominated by conservative tastes, this commonly results in heated debates, literary nationalist arguments about the unique character of Arabic language for which music and rhythm are indispensable, and claims such as 'prose poetry is a conspiracy against the Noble Qur'an'. It is a travelling trope and has been around for some time. Khaled Furani cites a Palestinian poet who argued that an attack on traditional poetic forms was an attack on 'Arab thawabit (certainties)': 'You can destroy a people in one of two ways: its religion or its poetry' (Furani 2012: 86-87).

Much appears to be at stake. This is also evident in Egypt's prominent history, since at least the mid-twentieth century, of 'culture wars' in which Islamist movements and the state-sponsored al-Azhar University have been pitted against secular intelligentsias. Among early notable incidents was the scandal about Naguib Mahfouz's novel Awlad Haratina (The Children of the Alley: Mahfouz 1996; for context, see Shoair 2017) in 1959. It has been followed by numerous other prominent cases (Mehrez 2010). The state has played an ambiguous role, co-opting those same secularist intelligentsias in the name of 'enlightenment', presenting itself as a guardian of conservative values and faith, and exercising censorship and political oppression in a number of areas (Abaza 2010). Over the past years,

1 Montaser Abdel Mawgoud, whose work I discuss in this chapter, subscribes to this strict definition of prose poetry. His third volume of poetry - the one that got him into trouble - consists of prose paragraphs that few Egyptian readers would recognise as poetry, but which according to Montaser do not qualify as prose poetry proper because when read together they create a narrative whole, and because they are full of intertextual references to religious scripture. 
there have been many media scandals, censorship cases, and lawsuits over 'defamation of religions' (izdira' al-adyan). ${ }^{2}$ Poetry and poetics thus have a contested history that resonates with key contested issues of societal values, faith, and political power in a way that appears to be linked with the 'problem-space' (Agrama 2012) of secularism and secularity. But what exactly is this link, and is the secularity of poetry and literature really the main factor behind their propensity to instigate scandals and conflicts?

\section{A bubble of world literature}

At the end of October 2015, the Tanta International Poetry Festival was held for the first time, bringing together poets from Egypt, other Arab countries, Europe, and Latin America. An initiative of the poets Mahmoud Sharaf from Tanta, and Montaser Abdel Mawgoud from Alexandria, the festival followed a new format for literature festivals, in which readings are not held in dedicated cultural spaces but instead go 'to the people' in schools, universities, cafés, and streets.

The organisers' aim of reaching a non-specialist audience was not easily accomplished. Few events had a substantial general audience. The Arabic poets in attendance all wrote either free verse or prose poetry. A poet from Cairo told me that at one of the better attended lectures at Tanta University, a student sitting next to him in the audience had commented to him: 'But what they're saying isn't poetry, right?' Controversy in the literary circles of Tanta had preceded the festival because some local poets had complained about being excluded from the festival. As a compromise, an event dedicated to young local poets was held on the last day of the festival, and it was well attended by the young poets and their friends.

In the years that followed, the Tanta Poetry festival has been more successful in bringing together different audiences and involving local literary circles. But in the first year, the attempt to bring avant-garde poetry into contact with a provincial city left the milieus involved largely intact. The invited guests from

\footnotetext{
2 Egyptian Penal Code § 98.I criminalises defaming or showing contempt (izdira') for 'heavenly religions', i.e. Islam, Christianity, and Judaism. Often dubbed a 'blasphemy law' in Englishlanguage media, it sanctions public acts and expressions that offend religious sentiments and disturb social peace. With very few exceptions, sentences based on the law have been handed down for expressions that offend Muslim sensibilities (Eshhad 2016). The law is a prominent case of a secular legal norm that in practice guards the sensitivities of the followers of the majority faith (Mahmood 2009).
} 
Egypt and abroad had a good time together and crafted networks and friendships. The Ministry of Culture had its representative event with pompous opening and closing ceremonies. Young local poets had their dedicated symposium. Senior local poets who were not invited to the festival could feel safely confirmed that the organisers did not value really good poetry. Few inhabitants of the city came into contact with the festival at all.

Two themes were conspicuously absent at the festival. The first was politics. Egyptian poets at the festival were divided into supporters and critics of the regime, and especially the latter avoided talking about politics. Another absence was more consensual. The poets at the festival largely shared a secular approach, be it in regard to their lifestyles, their politics, or the kind of poetry they produced. They employed poetic language in experimental ways that highlight human innovation, transformation, and uncertainty. Their poetry differed greatly from what Khaled Furani (2012: 66) has described as the traditional discipline of classical 'amudi poetry - traditional not simply in the sense of sticking to old ways, but in the sense of a moral commitment to an assemblage of language, aesthetics, and divine power. This is not to say that prose poetry cannot be spiritual, even pious. The work of Montaser Abdel Mawgoud, to which I devote more attention later, certainly is. But the milieu of world literature that came together in an international poetry festival carefully dealt with religion as a non-issue.

Michael Allan (2016) argues that despite its striving to unite humanity, 'world literature' is a limited space, guarded by a fundamentally secular understanding of what counts as literature. According to Allan, the unmarked category of 'literature' is secular not simply because the literati are not very religious (although in the literary avant-gardes of Egypt this is also often the case), but because what gets recognised as world literature involves forms of reading and writing based on a this-worldly understanding of humanity - to the exclusion of reading and writing in a religious framework. However, while this may be true of Egypt's cosmopolitan literary avant-garde, it is not generally true of literature in Egypt. At literary events in more conservative scenes (highbrow and popular alike), an understanding of literature limited and guided by faith is common, even prevalent. This understanding can gain international recognition and financial success as well, mainly thanks to highly remunerated poetry competitions and prizes in the Arab Gulf states that often promote classical and mainstream poetic tastes.

'Literature' in the sense reproduced by international literature festivals and avant-garde milieus can most successfully maintain the illusion of its unmarked normality when its communicative bubble remains intact, protected from conversations and claims that may challenge or reject it. This doesn't mean that people in these circles are necessarily satisfied with it being so. The first edition of the Tanta International Poetry Festival was designed to move out of the bubble and 
enter a conversation with wider audiences. However, this conversation had an avoidance of politics and religion as its precondition. Furthermore, paradoxically enough, the festival was a pleasant experience for most participants because the attempted conversation with wider audiences did not go very far.

This was even true between different groups of participants. Employees of the Ministry of Culture who were responsible for the logistics mostly cultivated a formal, pompous style of address that stood in a marked contrast to the understatement that most poets invited to the festival cultivated in their recitals. At one event, held at a private coffee shop and bookshop, a moderator from the Ministry of Culture presented the speakers through long speeches in rather overarticulated Classical Arabic with many ornamental expressions, quotations, and moral lessons. One of the poets she presented was S.F., an Iraqi living in the Philippines. His poetry was in Classical Arabic but void of ornament, and his style recital understated, intentionally close to ordinary language - which stood in in stark contrast to the moderator's style. In the discussion, he said that he found it difficult to identify as an Iraqi, and questioned whether Iraq really exists anyway. The moderator intervened in an apparent attempt to sooth him: 'It shall return! It shall return, God willing.' S.F. replied dryly: 'And if He wills not?' The sarcasm of his comment was lost on the moderator, who continued her carefully rehearsed performance. Afterwards, once left among themselves, invited festival participants poked fun at grammatical errors the moderator made in her Classical Arabic oratory.

Two quite different aesthetics and attitudes towards literature and language met but did not collide in this event. Their encounter caused some friction, but it was sufficiently softened by politeness during the event and by ridicule in private conversations after the event. But sometimes communicative bubbles burst. This can be troublesome, even dangerous, as became evident on one occasion.

On the second day of the festival, Mukhtar and I attended a workshop titled 'The state of poetry in Egypt', which had been organised by the Alexandria Library in conjunction with the festival. Montaser Abdel Mawgoud was among the participants. In an opening speech, H.S. from Cairo summarised the state of literary critique, supporting prose poetry as the poetic form that commands the openness necessary to give a literary account of a changing world. The next speaker, F.A. from the southern Egyptian city of Qena, argued on transformation as the key concept. When writing, he explained, you transform into a different being. He saw the main problem facing contemporary poetry as being the limited education of the audiences: because of the classical focus of university curricula, even literature students were unable to understand the poetry of Salah Abdel Sabour, who today is among the uncontested masters of modernist taf'ila poetry. 
The debate might have well continued as a safe and well-worn debate among writers about how to deal with commercial popular culture and the limited societal reach of highbrow literature. But the discussion took a different turn through the intervention of two men who introduced themselves as professors at the alMansoura branch of the al-Azhar University. One of them questioned the principle of openness proclaimed by the speakers on the podium. Instead, he saw the problem of 'the overthrowing of identity'. 'Identity' (al-huwiya) in the Azhari professor's usage did not mean just any kind of identity. It is an established political and religious shorthand for the demand that Egyptian society, culture and politics must be clearly and firmly Islamic. The idea of openness and transformation without clear moral guidelines was for him tantamount to the overthrowing of the Islamic foundations of society and its values. He specifically took issue with prose poetry, questioning the need for poetic innovation: 'Does 'amudi poetry lack the capacity to express some things, or is this the poet's shortcoming?'

A debate about identity followed. Dr M., the other of the two Azhari professors, intervened to link the question of identity with the question of the moral purpose and message of literature:

For example, in writing about sexual harassment: if the poet writes of what is blameworthy, does he increase the vice (radhila), or does he present a critique and attack the vice?

The moderator of the session interrupted: 'Is that the role of poetry?'

Dr M.: The creative producer (mubdi ) belongs to the elite of society. Therefore, if he writes about vice and leaves it at that, it is as if he reinforced it. Second, as related to Islam and openness/open-mindedness (tafattuh): the fault is not in the thing but how it is used. There is a difference between the affairs of religion (din) and this world (dunya). In religion there are certainties (thawabit) that do not change. But 'You are more knowledgeable about your world' [a saying of the Prophet Muhammad]. However, openness does not mean infringing on the certainties.

S.A., a poet from Cairo, got angry and tried to interrupt Dr M., while F.A. suggested we should think of identities as multiple:

F.A.: Estrangement (ghurba) is something fundamental for the poet. Simply by writing, he is in a state of estrangement from his ordinary life, also language-wise. We carry tens of voices: all those I was influenced by but with whom I cannot speak. Identity is identities, elements; each element has its specifics. Some of them are fixed/firm (thabita).

The first Azhari professor: Identity is fixed/firm (thabita); the shape changes.

S.A.: What brought religion into this!? 
The first Azhari professor: Are we not Muslims first of all?

S.A.: Not me! I'm Egyptian and I'm Muslim. Egyptian first!

F.A. did not support S.A.'s nationalist identitarian stance, but instead went on to argue that identity has moving and stable parts, and requires continuous struggle (which the Azharis found somewhat more agreeable), and insisted that humans have a 99 per cent shared human identity. But S.A., who had become very agitated, argued there was a link between language and alienation that came from two directions: from reciting the Qur'an in a Gulf Arabic accent to youths writing in Franco (Arabic in Latin letters). 'Your identity is lost in the middle,' she concluded. H.O., a poet from the local literary scene of Tanta, joined the debate and gave a long presentation on literary concepts, relating them to Sufi and other religious concepts, and finally arguing in support of 'identity' and religion as a framework of truth and certainty: 'there are certainties (thawabit), such as that we are below on Earth and God is above us'. He was interrupted because participants from Alexandria and Cairo had to catch their train, and the workshop ended without conclusion.

Among the festival guests who stayed in Tanta, the discussion continued for a long while afterwards. Montaser described it as the worst symposium he had ever experienced. S.A. was furious: 'I run into such people [meaning the two Azharis] often and they always know how to ruin everything. Their presence was intended as a provocation.' F.A., in contrast, said that it was wrong to get so agitated. The reply should have been calm, without allowing the debate on thawabit and identity they opened to dominate the discussion: 'When it resulted in commotion, they won.'

The people who participated in this debate were not simply divided into religious and secular camps. The positions were more plural, including F.A.'s postmodern humanism, S.A.'s Egyptian nationalism, and H.O.'s search for a union of creativity and piety. The Azhari professors challenged two of the key implicit terms under which they could join in a friendly debate: first, the appreciation of literary expression and innovation as valuable in their own right, and second, the inclusion of soft religious identitarian claims and the exclusion of strong ones. The Azhari professors won, not in the sense that they would have convinced anybody of their stances, but in the sense that they broke the bubble of secular world literature in which nationalist and cosmopolitan, modernist and postmodern visions could coexist. To survive in a society where other sensibilities prevail, such visions need a selective audience and the exclusion of certain divisive issues. There are places where secular modes of reading of the kind ana- 
lysed by Allan (2016) successfully silence other modes, but they are rarely found in Egypt.

The selectiveness and exclusiveness that are necessary to enable certain conversations evidently casts a shadow of doubt on the aspirations of modernist and postmodern avant-gardes for openness and communication with a generic humanity - aspirations that were clearly stated in the workshop. In this regard, I agree with Allan. But the Azhari professors did not challenge prose poetry because of its 'secular provinciality' (Allan 2016: 130). They took the demand for openness and open-endedness seriously, and rejected it because it would leave vice unchallenged and relativise the firm grounds of their project of revitalising and purifying Islamic identity. ${ }^{3}$

\section{'More dangerous than those who call for unbelief'}

Why would two professors of al-Azhar travel from a different city to an otherwise poorly attended literary workshop? They had come with the specific intention to meet Montaser. During a break in the workshop, they spoke with him and pressed him about his third poetry volume, which in their view was opposed to the Qur'an. They demanded that he withdraw the work in a manner that he understood as a threat. He was so frightened by the encounter that he did not attend any public literary events for more than a year.

Born in 1973, Montaser Abdel Mawgoud has been active in the literary scene since the early 1990s, and while his work is not known to wider audiences, he has gained recognition in the avant-garde circles of Cairo and Alexandria, and has been invited to some literature festivals in Europe and Latin America. Until 2016, he worked as a teacher of Arabic and Islam in a government school, 4 and lived with his family in a low-income informal area in Alexandria. Writing has been his

3 This was not the last incident of its kind at the Tanta International Festival of Poetry. At the closing ceremony in 2020, a local poet in the audience objected to the form and content of poetry recited by the Alexandrian poet Amina Abdallah, and after the event, wrote a post on social media in which he accused her and the festival of conspiring against the Islamic faith and the Arabic language, and demanded a public apology. In contrast to Montaser, who did all he could to avoid public exposure and escalation, Amina Abdallah chose to publicly confront the accusations, which is in line with her long-term record as a poet who writes in explicit opposition to religious conservatism and conventional gender roles. For an account of the incident, see Mamduh 2020. 4 Arabic teachers are always also Islamic religion teachers in Egyptian government schools, which is telling of the intimate link between faith, doctrine, and language. 
passion since his youth, and he has actively cultivated and developed his writing skills since his school years.

In 2012, Montaser released his third volume (diwan) of prose poetry titled Thammat ashya' lan yujarribaha (There Are Things He Will Not Try, Abdel Mawgoud 2012). Written in a dense, poetic prose without a verse structure, the volume offers an imaginative retelling of key events from the Qur'an and the Bible, featuring the interactions and (inner) struggles of heroes and anti-heroes of the scripture, starting with God, Satan, and Adam, and continuing to include many more in a poetic account of the relationship between humans, prophets, and the Creator. There Are Things He Will Not Try can be read as an invitation to put oneself into the position of the key figures of the Scriptures. For example, Satan's fall from grace is told from the point of view of an exchange of glances between Satan and Adam:

$$
\begin{aligned}
& \text { خلق الله آدم ونفخ فيه من روحه، بسجود الملائكة له وقف الأسير، نظر ناحية العرش، لم تمنعه حجب الضباب الكثيف } \\
& \text { أن يستشعر سعادة الرب، نظر ناحية الملائكة الساجدين فانتابه شماتة صغيرة متذكرا كراهيتهم له، ثم حجد آدم بنظرة } \\
& \text { طويلة وحين التقت الأعين قلب آدم الأسماء كلها بحثا عن اسم لأثر تلك النظرة في نفسه. } \\
& \text { علم الأسير أن لن يستوقفه أحد، هبط مثقلا بفكرة خلوده. لم يخطط لشيئ بعد ولسبب ما تذكر قصره الرخامي وما فيه } \\
& \text { من شموع لن تشعل بعد اليوم. }
\end{aligned}
$$

God created Adam and blew into him some of His spirit. As the angels bowed down before Adam, the Prisoner [i.e. Satan] remained standing. He looked towards the throne; the dense veils of mist did not prevent him from sensing the happiness of the Lord; he looked towards the prostrating angels, and a little malicious joy befell him as he remembered their hatred for him; then he cast upon Adam a long glance of rejection, and when their eyes met, Adam examined all names in search of the name for the effect of that glance on him.

The Prisoner knew that no one would stop him; he descended, burdened with the thought of his immortality; he planned nothing yet, and for some reason he remembered his palace of marble and the candles in it that would not be lit after today. (Abdel Mawgoud 2012: 22; my translation)

Some poems contain direct intertextual references to the Qur'an, such as the following poem about the encounter between Moses and al-Khidr. Their encounter as told in the Qur'an (18:65-82), has been a major source of inspiration for Sufi thought and wider literary imagination (see Toorawa 2014), because in it Moses, representing prophecy and the Shari 'a, is given a lesson by God to acknowledge his ignorance of deeper truths that are known by al-Khidr. In the original version of the story, God sends Moses (Musa) to meet a servant of God more knowledge- 
able than Moses. ${ }^{5}$ Although he is told to ask no questions, Moses keeps asking and questioning al-Khidr's acts that seem unjustified and unreasonable to him, until al-Khidr reveals to Moses the hidden reasons that prove his acts righteous, and says 'this is the parting between me and you' (Qur' an 18:78). The poem tells a slightly altered version. Qur'anic phrases in the poem are in italics in the translation; they are not marked in the Arabic original.

$$
\begin{aligned}
& \text { عندما تلقى رجلا أوتي من العلم ما لا تستطيع عليه صبرا، فلا تسأله أن يعلمك، بل لا تسأله عن أي شيء... فقط اتبعه } \\
& \text { محافظا على مسافة تسمح لك بتنسم عبير رقته وهو يخرق السفينة، والانتباه لآلية الموحى إليه بقتل صبي كان سيرهق } \\
& \text { أبويه كفرا، فإذا ما استنرت بنور تخليص الأعمال بمسبباتها الأولى؛ سبقته يداك إلى إقامة جدار كان نقضه هزيمتك وفوز } \\
& \text { قرية من اللئام، فيبس في وجهك ثم يخبرك معتذرا:.... وهذا أيضا فراق بيني وبينك..... } \\
& \text { ثم يمضي بعباءة خضراء تزحم خيالك كلما تذكرت أرض مصر. }
\end{aligned}
$$

When you meet a man blessed with knowledge for which you could not hold patience, do not ask him to teach you, and do not ask him about anything ... only follow him, maintaining a distance that allows you to inhale the scent of his graciousness while he makes a hole in the ship, and pay attention to the technique of the one inspired by revelation to kill a boy who would have oppressed his parents with unbelief; and once you gained insight into the light that justifies the acts through their original causes, your hands preceded his in building up a wall,6 the collapse of which would be your defeat and the victory of a village of lowly folks; and so he smiles cheerfully into your face and tells you in the way of an excuse: ... This, too, is the parting between me and you...

Then he passes in a green cloak that besets your imagination every time you remember the land of Egypt. (Abdel Mawgoud 2012, 69; my translation)

5 The servant of God is not named in the Qur' an but is identified as al-Khidr in Muslim traditions.

6 This refers to the third strange act of al-Khidr. When he and Moses arrive in a village where the inhabitants refuse to offer them hospitality, al-Khidr goes and restores a wall that is about to collapse, and does not ask the villagers for a wage. In the Qur'anic text (Qur.18:82), he explains his act to Moses: 'And as for the wall, it belonged to two orphan boys in the town; and there was under it a treasure belonging to them; and their father was a righteous man, and your Lord intended that they should attain their age of full strength and take out their treasure as a mercy from your Lord [which is why the wall should be restored to stand until then]. And I did it not of my own accord. That is the interpretation of that for which you could not hold patience.' (Translation freely after Khan 1996; for the original verse and other possible translations, see The Qur'anic Arabic Corpus, http://corpus.quran.com/translation.jsp?chapter $=18 \& v e r s e=82$.) 
On 23 February 2017, I met Montaser for an interview in an apartment in Alexandria to which he and his family had temporarily relocated to stay away from trouble. ${ }^{7}$ He told me that his aim in the book had been 'neither to sacralise the sacred, nor to defame it, but rather to act upon the principle of [...] an aesthetic exploration of the religious heritage'. His aesthetic search turned out to be much more controversial than he anticipated, however.

Contemporary Arabic poets have often been drawn to Qur'anic themes, forms, and phrases. When they have done so in ways that are not clearly devotional and reverent, this has repeatedly resulted in scandals. There is a widespread sensibility in Egypt and elsewhere in the Muslim world against any sort of playful or creative retelling of the Qur'an, and an even stronger antipathy towards changing parts of it and attributing words to God (Wild 2001; Toorawa 2004). This sensibility is also widely shared among Egyptian Muslims who are not supporters of Islamist movements. However, Islamist groups have played a prominent role in Egypt's recent 'culture wars', which have involved many lawsuits and censorship cases. The most effective form of censorship is societal pressure. With the exception of members of the upper classes who can enjoy the luxury of seclusion and mobility, most Egyptians whose acts or writings are interpreted by others as heretical or as unbelief must continue to cope with conservative views within their family, at work, when they interact with their neighbours, when doing business, and when they take their children to school.

Because the distribution of contemporary experimental poetry is so limited in Egypt, the volume did not generate public controversy - although it received positive critiques in avant-garde literary circles, which usually encourage such imaginative explorations and experimental aesthetics. However, the volume did not stay inside this bubble.

I know of the following events from Montaser's and his wife's accounts of them. Aside of my short encounter with the two Azhari professors in Tanta, I have not been in contact with his detractors, because doing so might cause him additional harm. Until his departure from Egypt, Montaser consciously avoided making the issue public because he feared that it might result in criminal charges for defamation of religions against him.

Montaser had previously been criticised for his poetry by colleagues at the school who were close to the Muslim Brotherhood. They had taken issue with a reference to masturbation in his first volume and to Christian imagery in his second volume. He told me he anticipated similar criticism with regard to his third

7 Unless otherwise indicated, all interview passages with Montaser Abdel Mawgoud cited in the following are from the same interview. 
volume, but expected no further consequences. However, after reading his third volume, the same colleagues accused him of distorting the word of God. They also submitted a complaint to the school administration, stating that his poetry offended God, angels, and prophets, and that his work as a teacher of Arabic and Islam therefore constituted a threat to children's minds. They must have passed on this message to others, for Montaser began to receive threatening phone calls from withheld numbers. His wife also received phone calls and was approached by people in the market who told her that her husband was an infidel (and thus, by Islamic law, not her husband) and that she should leave him or accept the consequences. In the neighbourhood where he lived, Montaser was once stopped by two men who told him he should renounce his book, that it would be permissible to kill him as an infidel, and that he should consider this the final warning. After that, he did not leave or enter his home in the company of his wife and children, used detours when he left or returned, and sometimes slept at work. He reported the threats to the police, but the officers in the station showed no interest in protecting him. In summer 2014, he managed to get transferred to another school, but the phone calls continued. In 2016, a new complaint was filed against him. Reacting to the pressure, he took unpaid leave from his work later that year.

Montaser's situation was aggravated by the fact that he does not belong to Egypt's well-connected bourgeoisie and could not afford to relocate to a more secluded neighbourhood or to find different work. He had powerful allies, however: an international secularist community of world literature that was connected with him through literary festivals to which he had previously been invited. Through these connections, he received a small scholarship that allowed him to temporarily relocate to an anonymous middle-class neighbourhood, and in December 2017, he was able to emigrate from Egypt to Norway with the help of ICORN, a programme that supports writers and artists at risk (Frantzen 2019).

These events began to unfold in autumn 2013, shortly after the civilian government of the Muslim Brotherhood had been overthrown by a military counter-revolution. Something about his book was so disagreeable to supporters of Islamist movements that in the middle of a military coup against an Islamist president, they channelled some of their efforts towards trying to persuade and intimidate the author of a volume of highbrow poetry. Montaser had supported the 30 June movement against the Muslim Brotherhood, but he did not support the military rule that rose to power afterwards. This was not a matter of politics in the guise of theology.

Montaser paraphrased the accusations made against his work:

There were accusations, for example: 'Why do you rewrite the contents of the holy Scripture? Don’t you like the original text? Do you want to offer an alternative text?' I told them: 
'Not at all.' Other people said: 'You attribute fabricated words (tataqawwal) to God, that's wrong.' [...] Others said: 'There are certain passages where you differ from the text of the Qur'an in an evident manner.' I told them: 'That's true, I differed from it in a clear manner but I didn't contradict it in a manner concerning the Sharia (fi amr shar i $).{ }^{8}$ I differed from it in the depiction of a historical event, which is the encounter of al-Khidr with Moses (Musa), peace be upon him. I employed an artistic technique in my poem with al-Khidr. You know the idea of the mirror in which you see things inverted. So in the text I constantly imagine that Moses does the opposite of what he did in the Qur'an. I imagine that he didn't ask, I imagine that he acted before al-Khidr when building the wall. In the end they still come to the same conclusion. You did all you should, but still it ends with 'the parting between me and you', because that is the nature of things. If you want to learn, you will learn from more than one field. And I left the circle open.

\section{$[\ldots]$}

Unfortunately, most accusations come from people who are not professionals in dealing with an artistic work, they are just teachers. So they believe that what is taught in prep and secondary schools is the peak of literary creativity, and that [what I write] is opposed to it. These are the same milieus that circulate the lie that prose poetry is a conspiracy against the Noble Qur'an. When I asked a group of those people: 'Why do you say so?' - what was their interpretation? One of them offered a very strange argument. He said that the preservation of the columnic ('amudi) form in old Arabic poetry was intended by imams and scholars of law for centuries to avoid confusing poetry with the text of the Qur'an, which is written in the shape of a prose paragraph (kutla nathriya). I of course said to them that the Andalusian poets who produced the muwashahat disjointed the structure of those poetic columns. ${ }^{9} \mathrm{He}$ said: 'No, there you are talking about something else, those are all virtuous imams like Ibn Hazm. ${ }^{10}$

In these accusations, issues of form and content are closely intertwined. Playfully reimagining passages from the Scripture and showing angels, prophets, God, and Satan as complex characters was - from the point of view of conservative readers - a severe break with the respect and awe that worshippers should show towards the words of God. At the same time, the style and written shape of prose poetry also confused and threatened the distinction between poetry and revelation. This

8 Shar', synonym of shari'a, is used by Montaser here in the wider sense of normative practice, including worship and ritual as well as norms of human interaction that may be translated as 'law'. 9 Muwashahat (sg. muwashah) is a style of poetry developed in medieval Muslim Spain. It uses changing rhythms and rhymes, combines classical and dialectal Arabic, and does not rely on the double verse and the canonical sixteen Arabic metres. Because of their formal variation and flexibility, Andalusian muwashahat have been drawn upon as inspiration and tradition by experimental Arabic poets of the twentieth and twenty-first centuries.

10 Abu Muhammad Ali Ibn Ahmad Ibn Sa'id Ibn Hazm (994-1064 CE), author of the famous treatise on love The Ring of Dove (Tawq al-hamama, Ibn Hazm 1953). 
enforced the impression that the volume is an attempt to rewrite divine revelation. A less explicit, but important contributing factor was the medium of a book that gave the poetry gravity and importance that the spoken word may not have (this was why Montaser was criticised by his colleagues for mentioning masturbation in his first volume, although he used words far less explicit than those that might be used, for example, in a men's gathering in a café).

In the interview, Montaser reiterated the common claim in avant-garde circles that most Egyptians do not know how to read literary works the right way (see Allan 2016). But his detractors did read his volume - in a way that they understood to be the right one. And although the accusation later escalated to that of unbelief, his colleagues initially accused him of subverting faith from within which in their view was possibly even worse than unbelief:

Montaser: One of the fundamentalists who gave the book a thorough reading said to me: 'The title itself is problematic. [...] 'There are things he will not try' - [...] do you mean the angel?'11 I said: 'That's right.' He said: 'So you alter the word of our Lord and you want to say that the angels who are created from light can't do something and humans can do it?' I told him that I'm not altering the word of our Lord and that's really how it is, an angel can't do things a human can do, and vice versa. He told me: 'Like this, you are more dangerous than those who call for unbelief [...], because you try to destroy religion from within and with its own language.' I asked him: 'Are you serious?' He said: 'Yes indeed, and if you didn't realise this, you should ask our Lord for forgiveness [...], you are a sinner inadvertently, so withdraw the copies and burn them and forget that book.'

Samuli: I really feel that that's what makes the poem so controversial, because it doesn't enter religion from outside; it takes the religious scriptures and stories and lives with them.

Montaser: Yes, lives with them.

Samuli: And when you look at the history of the Christian and Islamic religions, you always find the heretic (zindiq) more dangerous than the infidel (kafir).

Montaser: That's right, although he [the heretic] is not an infidel.

Samuli: Although he's not an infidel. That's because he's close to you and can confuse you and your certainty (yaqin) in a way an infidel can't.

11 The volume concludes with a narrative sequel of poems about an angel who is commanded by God to send a series of dreams to a human, whereby the human is eventually confirmed in his faith but the angel is left longing for the human's friendship. 'There are things he will not try' is the angel's recognition that there is a sphere of human freedom that he as an angel cannot share (Abdel Mawgoud 2012: 93). 
Montaser: That's right, and because he uses the same means (asalib) and language as you do. And that's what caused the problem.

Here, some clarification of terms is needed. Why call Montaser's poetry heretic and not secular? After all, a number of researchers (Asad 2003; Furani 2012; Allan 2016) have argued that contemporary poetic forms are inherently secular. In his ethnographic research with contemporary Palestinian poets, Khaled Furani (2012) defines the secular as a peculiar quality of modern states, power, and language that has less to do with how religious people are and what lifestyles they have, and more to do with the kind of position religion is relegated to in a world structured by ideas such as progress and freedom:

The secularity of these shifts resides in what poets do with words [...], which profoundly resonates with the modern and contingent career of the secular as an ontology and epistemology of distancing from what or whom it anoints as 'religious'.

[... T] he secular lives in the grammar of our modern being and forms, not only beliefs (theistic or otherwise), but also in conditions in which [...] experiences of the oneness of human action splinters into autonomous realms. (Furani 2012: 14-15)

Thinking in the terms proposed by Furani, the Tanta International Festival of Poetry was secular indeed. It treated religion as something distinct from literature, and avoided themes and discussions that might jeopardise that safe distinction. Montaser's third volume of poetry, in contrast, is something else, and something more dangerous. The volume clearly does not distance itself 'from what it anoints as "religious"' (Furani 2012: 14). On the contrary, it deals with divine revelation head on. Practically every page of it deals intimately with God, creation, and revelation. And rather than splintering human action into autonomous realms, the volume connects the conventionally separate realms of divine speech, and human poetry and prose.

Furani's idea of a oneness of human action that existed before secularism splintered it appears rather nostalgic, and would probably not withstand historical inquiry. And in any case, different ways to unite and divide were at work in Montaser's poetry, at the Tanta poetry festival, in the intervention of the Azhari professors, in the reactions of Montaser's colleagues to his work, and in the support he received through his international network.

In contrast to secularism ('almaniya), which is a way to restrict or evade the social and political power of God-oriented faith, and also in contrast to (accused or actual) unbelief (kufr) or atheism (ilhad), heresy (zandaqa or hartaqa) means expressing or practising a faith in a way that others sharing the same faith find misguided, wrong, and dangerous. There Are Things He Will Not Try is an expli- 
citly pious work written by a Muslim who explores the divine revelation recognised by Muslims. This is why it was understood as a heretical attack from within by some of its readers, which is a more offensive and exposed position.

In October 2019, I visited Montaser and his family in Norway, where they had moved at the end of 2017. I gave him a summary in Arabic of an earlier version of this chapter that had just been published (Schielke 2019). He had recently published his fourth collection of poems Fi madih al-baladat al-saghira (In praise of small places, Abdel Mawgoud 2019), and it was receiving a positive critical echo. In line with Montaser's striving to write prose poetry as a strictly self-containing genre, it is a less accessible and more abstract work than There Are Things He Will Not Try. Montaser pointed at the paradox (in his view) that his new collection contains far more dangerous ideas on religion than the previous one did, and yet he released the book with what he described as a conservative publisher in Jordan, and neither they nor anybody else objected. One of the poems (Abdel Mawgoud 2019: 24-25) imagines a new, peculiar, and unobtrusive religion that the narrator is invited to join; another (p. 40) reflects about faith, unbelief, indecision, and the terror of being able to make up one's mind; a third (p. 41) sketches a scene of resurrection where the resurrected question God instead of being questioned by Him. He argued: 'You can communicate more dangerous ideas in the context of a philosophical book like In Praise of Small Places.' And this indeed distinguishes heresy from philosophical thought experiments. There Are Things He Will Not Try addresses the heart of religious certainties and enters a dialogue with God, prophets, and Satan. Most gravely, it does so through an intertextual engagement with the Qur'an. That is in itself far more heretic and dangerous than any ideas one may develop in a philosophical context and genre that maintains its separation from Scripture. Montaser's third diwan has more heretic potential, while his fourth diwan enjoys more secular leeway.

\section{A postmodern heresy}

The accusation that prose poetry is a conspiracy against the Noble Qur'an is grounded in a suspicion that underneath the seemingly inoffensive secularity of the prose poem looms an abyss of heretical imagination. Experimentation in form appears as an invitation to a path of moral and theological error. Of course there is no real conspiracy; but form, morals, and theology are linked indeed.

In my reading of the work of Talal Asad (1986: 15), orthodoxy is not a given position, but a relationship of power where one side in a debate is able to establish its way to relate with God as correct, accepted, and authoritative. Conse- 
quently, heresy is an unauthorised way to relate to God. Montaser's work is heretical (or heterodox) in the sense that it infringed on an intersection of sensibilities among conservative readers. On a theological level, it produces a poetic imagination of the human-God relationship that challenges its hierarchic nature, which goes against the grain of societally orthodox and doxic understandings of that relationship and its aesthetic dimensions. On a formal level, it infringes upon hegemonic lines of division between revelation and poetry, literary imagination and religious truth that are produced by both secular institutions as well as God-fearing traditions of reading and writing. These two dimensions together made Montaser's work more dangerous than unbelief in the opinion of one of his readers.

Heresy is not simply negative, however. It adds something new: a new perspective, new ideas, new ways of doing things, speaking, or feeling. It is not by coincidence that one of the concepts for heresy in Islamic vocabulary is novelty or innovation (bid'a, see Fierro 1992).

There Are Things He Will Not Try has indeed the quality of moral and aesthetic novelty or innovation, insofar that it imaginatively adjusts and rethinks the way in which humans communicate with God. It transforms an authoritarian relationship of revelation between God the speaker and the human listener, into a dialogical relationship where humans have the power to influence the line of revelatory communication by means of their imagination. This imaginative move has far-reaching theological consequences. By empowering humans as participants in a dialogue with God, it unsettles sensitively guarded spiritual and societal certainties (thawabit) about how humans should relate to God - and by extension other humans. These include respect and awe for God's absolute authority over humans; a corresponding respect for divinely legitimated human authorities; a proper emotional state of gratitude, trust, and fear that humans should express to God; and moral norms regarding sexuality, gender, societal reproduction, rights and obligations, community relations, and the relationships between Muslims and non-Muslims. This is what Muslim Egyptians usually mean when they speak about certainties (thawabit). Importantly, thawabit do not refer to subjective certainty, which is yaqin in Arabic. Thawabit is the plural form of thabit, which means firm, fixed, and unchanging. Thawabit are objective certainties outside and independent of human deliberation. From a conservative or activist Muslim point of view, subjective certainty (yaqin) relies on God's objective certainties (thawabit) being beyond doubt, and is guaranteed and realised by humans' active submission to the power of God. This vision is not the prerogative of committed religious activists. It is a vast conservative societal mainstream that can go hand in hand with militarist nationalism, and it saturates most state institutions even when those institutions and their employees are simultaneously 
involved in the secular practice of subjecting religion to the primacy of the nation state.

Furthermore, Montaser's poetic text is more than literary, in the sense that it strives to unite the languages and genres of poetry and revelation. This was explicit in the original working title of the volume, The Bible Written by Me, which Montaser had to change before publication because the publisher deemed it too controversial. In a conservative understanding, the division between revelation and poetry can be crossed in only one direction: the revelation can and should inspire and guide poetic imagination and language. Confusing this division means crossing it in both directions, so that poetic imagination can compete with theological reason, and poets can speak back to God and prophets. The gravity of this step is echoed both in the accusations of altering the scripture Montaser faced, as well as in his colleague's claim that poetry needed to be clearly marked as different from the Qur'an.

Heretical Islamic ideas about humans, God, and prophecy have a history almost as old as Islam itself (Jumá 2007; al-Ma'arri 2016). Montaser's poetry carries echoes of that tradition, but it is more explicitly grounded in an international literary genre that was first developed by francophone authors in the nineteenth century and that spread through the network of secular world literature in the twentieth century (al-Janabi 2015). This is reflected in the names he referred to as sources of inspiration during the interview, which include internationally known authors of prose poetry in Arabic and foreign languages. ${ }^{12}$ The heretical potential of his poetry is thus situated in a distinctly postmodern and cosmopolitan tradition. But unlike some other poets in this tradition, Montaser does not strive to marginalise religious scriptures and the power of God over humans in his writing. Instead, in There Are Things He Will Not Try, he connects a cosmopolitan postmodern tradition that has romantic and modernist elements with an Islamic one, and comes up with an altered mode of communication between humans and God.

Montaser told me that in his youth he began writing classical 'amudi poetry but did not feel at ease with the genre: 'I always felt that there was a distance between me and it; this is not what I want to bring out from within myself.' In the early 1990s, he discovered prose, free verse, and especially prose poetry as forms in which he could express himself better:

12 He mentioned, among others, Yaser Abdel-Latif, Charles Baudelaire, Suzanne Bernard, Jorge Luis Borges, Max Jacob, Abdul Kader al-Janabi, Iman Mersal, Mohamed Metwalli, Abdel-Moneim Ramadan, Arthur Rimbaud, and Rifaat Sallam. 


\begin{abstract}
I believe that prose poetry is connected with something important in the life of the modern human. In light of the explosion of knowledge and the communication revolution, who among us can count the things that are certain (yaqiniya) in our lives? You will find out that they are very few. And the more you read, the fewer the certainties (al-ashya' al-yaqiniya) become; until you discover that this is the nature of the matters (tabi'at al-umur); that the transient has become the constant now. It's natural that I know nothing. This is unlike in the old, classical eras when the world was clear and things were simple. [...] So prose poetry gives you the power or the virtue of dealing as a researcher with [your] creative work and the topics you speak about. In taf'ila and 'amudi poetry, this is not the case. [In those genres] you have to have that firm (thabit) stock of certainty (yaqin) on which you build your poem. So prose poetry is always the child of doubt, the child of uninhabited territories; and over time, you discover that it's closer to our spirit and that our spirit really does not have that clarity.
\end{abstract}

Montaser turns uncertainty into a virtue in a distinctly postmodern gesture that he links with his argument that metric styles (classical and modernist ones alike) are part of an either solid or unidirectional world, and therefore require a 'stock of certainty'. For him, these genres 'have come to a dead end' because the world is changing in a way that requires different ways of writing. He does not, however, subscribe to a postmodern abandonment of authorship. On the contrary, he expresses a romantic idea of literature as an expression of the author's self (which is commonplace in contemporary Egyptian literature). He also expresses a vision of a qualitative progression from past to present that is modernist rather than postmodern. What does distinguish him from Egyptian and Arabic literary and political modernists, though, is his affirmation of uncertainty as a positive condition.

Contrary to some other poets in his circles, faith in God is a matter of great importance for Montaser, but he emphasises that faith, too, is open ended and subject to transformation:

[I believe] that faith is a personal matter, that I craft it and it evolves together with my consciousness, and it is not a constant (thabit) dogma. My faith grows up with me and changes with me. Because of that, even these certainties (thawabit) [of faith] are in a continuing state of change.

Montaser seeks to explore without judgement the condition of uncertainty by means of aesthetics that are grounded in an ethos of constant renewal and innovation. And yet the idea of embracing uncertainty and exploring without judgement is enabled by a number of certainties and judgements. First and explicit is an underlying trust in the human capacity to adapt, adjust, and change, along with a positive moral valuation of change, uncertainty, and open-endedness. Second and less explicit is the global context of the rapid growth in human eco- 
nomic activity that has provided material resources, technologies, and organisational forms that result in diversification, transformation, sophistication, and also destruction of human ways of life - a process that also provides the political and economic resources that international literary avant-gardes require in order to exist and thrive. Third and least explicit is the institutional trust invested in the cosmopolitan milieu of world literature that provided Montaser with the means and resources to develop his poetry in a way that gains support and feedback from significant others within the milieu. ${ }^{13}$

The historical narrative of movement from a certain to an uncertain world that informs Montaser's search for new means of expression echoes Khaled Furani's argument about prose poetry in Palestine. According to Furani, the secular-modernist imperative to look forward and leave behind the old marginalises traditional poetic techniques and their ethical and spiritual grounding. He paraphrases the secular-modernist stance:

To be a citizen of the secular state of the world it is necessary to question the concept of meter and the practice of sound measurement that it enables. To persist in working with meter is to be enslaved by the past, to refuse to develop, and to refuse to be a poet of secular modernity. (Furani 2012: 80)

Furani argues (2012: 168) that an important outcome of this move is the increasing divide between literary specialists and wider audiences. While a more traditional understanding of authorship linked with classical forms places poets above their audience as providers of inspiration and guidance, a modernist, secular understanding places poets ahead of their audiences in time (as is made explicit in the word avant-garde), making communication between poets and wider audiences not only more difficult, but also less relevant from the avant-garde poets' point of view.

Furani's analysis resonates with Montaser's claim that the open-endedness and uncertainty of the contemporary world requires appropriate literary means, which classical aesthetics do not provide. Furani also helps to understand Montaser's relative lack of concern about reaching wider audiences. However, Furani's approach does not account for Montaser's precarious position in the face of accusations of heresy and unbelief. Neither does it help us understand why Montaser's third volume of poetry was fiercely rejected by some readers while his fourth book has caused no scandal.

13 For the way doubt and questioning are grounded in taken-for-granted certainties, see Wittgenstein (1969). 
The heretical potential of Montaser's poetry is grounded in secular, postmodern forms of trust, some of which he states, while others are implicit. These forms of trust are much more precarious and limited in scope, however, than the image of all-pervasive and utterly powerful secularity Furani depicts. In Furani's ethnography, the literary avant-garde and prose poetry have become 'regnant' as part of 'the secular as a dominant presence' (Furani 2012: 13); they command hegemony to define what counts as poetry, thereby 'silencing the sea' of traditional metres. (The Arabic word for poetic metre, bahr, also means 'sea'.) In Furani's reading, prose poetry becomes a case study of an omnipresent secular hegemony imposing itself on the world. In regard to Egypt, however, claims about 'the secular' being dominant and naturalised to the degree that it is silent, natural, and inevitable do not match with reality. Some forms of secularity have arguably become successfully naturalised in Egypt, most importantly the nation state. But the partial and contested nature of secular institutions, not to mention the precariousness of secular faiths and life-worlds, is a far cry from silent domination. This is also true of poetry. In Egypt, unlike in Furani's fieldwork in Palestine, 'the sea' of rhythmic, rhyming poetry and its accompanying spiritual foundations is far from silenced. It roars loud and remains the regnant form of poetry except on a few avant-garde islands that only make up one part of what Furani calls 'the poetic scene' (Furani 2012: 87). This is in fact a widespread feature of Arabic poetry worldwide that sets it apart from many other languages where free verse has become effectively normalised. Furani's claim about the silent dominance of prose poetry thus appears somewhat polemical, glossing over the remarkable persistence of rhyme and metre in mainstream Arabic poetry.

Allan's (2016: 130) argument about the provinciality of the secular 'world' of world literature offers a more nuanced vision. However, he locates the power to define 'literature' in one specific milieu that he presents as successfully hegemonic. I cannot judge whether this was true of Egypt in the colonial era or not. But in any case, in twenty-first-century Egypt, 'the secular state of the world' (Furani 2012: 80) is a minority niche that enjoys the privilege of symbolic power and international connectedness but does not command comprehensive cultural hegemony. In the Egyptian Writers' Union, at most events of the Ministry of Culture, and in commercially successful colloquial poetry, literature remains connected with the ethical underpinnings of the classical concept of adab (Jacquemond 2008; Pepe 2015), and poetry remains intimately linked with the musicality of metre and rhyme.

The way metre is used has arguably changed. Today, the flexible and accessible genre of taf'ila dominates over the arduous mastery of classical prosody with its formal constraints that require a longer process of learning and apprenticeship. It is also more widely appreciated by non-expert audiences that may 
find classical poems too heavy for their tastes. Furani describes taf'ila metred free verse as an intermediate form between the classical and prose poetry in Palestine (Furani 2012: 168). In Egypt, in contrast, taf'ila is not an intermediate; rather, it firmly and clearly occupies the centre. Taf'ila is the new dominant form of poetry in a society committed to nationalist progress, the commands of God, and a globally circulated popular culture at the same time. It comes in popular and highbrow varieties, in classical and colloquial Arabic, it is good for recital and reading alike, and it is recognised as poetry by almost everybody.

Consequently, although Montaser is well connected in the cosmopolitan scene, he explicitly describes himself as a marginal writer, not only in regard to mainstream tastes and social mores, but also in regard to the mainstream of Arabic modernism, which in his view continues to search for certainties - nationalist and developmental rather than religious, perhaps, but certainties all the same.

Early twenty-first-century Egypt is witnessing a progressive erosion of hierarchies and centre-periphery relations between high and popular culture. ${ }^{14}$ Both the standards for good literature as well as the borders of literature and non-literature have become less institutionalised and clear than they were in the twentieth century. There is ample space for a plurality of genres, including prose poetry, both highbrow and popular colloquial free verse, classical 'amudi poems, songs and rap, slogans and chants, jokes, aphorisms, social media posts, blogs, novels, short stories, journalism, sermons, self-help courses, film and telenovela scripts, talk shows, comedy, and more. This uneasy and often unfriendly plurality of cultural productions and styles has been accompanied by an increasing plurality of expressions of Muslim faith especially in urban bourgeois milieus since 2011. The political, militant, and Sunni scripturalist piety movements that dominated the first decades of the Islamic revival now mingle with neoliberal self-help-cumpiety media formats that make eclectic and effective use of commercial popular culture (Moll 2018); as well as alternative spiritualities in both traditional and eclectic Sufism - partly mediated by novels such as Elif Shafak's 40 Rules of Love (Shafak 2012; Sedgwick 2017). More controversial views in circulation include rejection of the Sunni tradition by those who embrace Shia Islam, liberal hermeneutics, irreverent speech about God and faith, and also outright atheism or non-religiosity. Many other genres resist categorisation - among them Montaser's poetry, which resonates with Sufi spiritualities, liberal hermeneutics, and Sunni scripturalism alike. Some of these currents do not unsettle conservative mores

14 This development began in the late twentieth century (Armbrust 1996), and has been accelerated during the past two decades (Jacquemond and Lagrange 2020). 
and understandings of humans and God - Sufism in particular is embedded in the clientelist structures of conservative Egyptian society, and has enjoyed regime support since 2013. Others are more likely to cause scandal - most importantly Shi'a Islam and atheism, but also some postmodern attempts to reimagine the human-God relationship, such as that by Montaser Abdel Mawgoud.

But what about those who search for explicit, firm certainties? Do poets who work with classical and modernist techniques really enjoy a comfortable 'stock of certainties' as Montaser claimed? We have to be attentive to their side of the story as well in order to better understand some of the links between literary aesthetics, moral and ethical stances, and certainty and uncertainty. Therefore, the next chapter turns to the life and work of a poet who also describes uncertainty as a key characteristic of our time - but draws different conclusions from that recognition. 